\title{
Physical-chemical and biochemical characterization of Buchenavia tomentosa Eichler fruits
}

\author{
Elanne Costa GLÓRIA ${ }^{1}$, Heloísa Helena de Siqueira ELIAS ${ }^{2}$, Elisângela Elena Nunes CARVALHO², \\ Luiz Gustavo Lima GUIMARÃES ${ }^{3 *}$
}

\begin{abstract}
The wild native species of the Brazilian savannah have attractive flavors and nutritive compounds. Among the Combretaceaes genus, the Buchenavia tomentosa Eichler plays an important role in popular medicine, however, little is known about its chemical composition. Thus, in order to a chemical-biological prospection in fruits of the Tocantins savannah, the aim of this work was to characterize the $B$. tomentosa fruits collected in the central and southern regions of Tocantins State, about some of its physical, physical-chemical and biochemical properties. The fruits, for this study, were collected in two regions (Palmas and Gurupi) in Tocantins State and analyzed in the parameters: coloration, centesimal composition, pectin, soluble solids, $\mathrm{pH}$ and acidity, vitamin $\mathrm{C}$ content and phenolic compounds. The study obtained results demonstrate that the fruits are of a light yellow color, are acidic, have high values of ${ }^{\circ} \mathrm{Brix}$ and glycidic fraction (carbohydrates). However, the high levels of vitamin $\mathrm{C}$

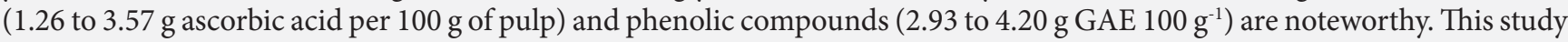
evidences a great nutritional potential for the fruits of $B$. tomentosa.
\end{abstract}

Keywords: savannah fruits; mirindiba; vitamin C; phenolic compounds.

Practical Application: The physical-chemical and biochemical characterization of Buchenavia tomentosa fruits become necessary in view of the lack of knowledge about its nutritional properties. In this way this paper presented results show that the fruits of this species can be characterized as acids, slightly sweet, little intense yellow color and potentially nutritious, highlighting the high levels of phenolic compounds and vitamin C.

\section{Introduction}

The savannah is the second largest Brazilian ecosystem and stands out for its great biodiversity, besides being an important agricultural frontier of the world. However, the process of agricultural development has undermined the ecosystem sustainability and contributed to the extinction of many species of animals and plants, including native fruit trees, wildlife base of support and source of food for local populations. In general, the fruits of the Brazilian savannah arouse an increasing scientific interest, due to their nutritional and functional properties, combined with the potential to add value and conserve the biodiversity of this biome (Siqueira et al., 2017).

The fruits of the savannah stand out because they have attractive organoleptic characteristics, present "sui generis" flavors and high levels of sugars, proteins, vitamins and minerals. They are consumed "in natura" or in the form of juices, liqueurs, ice creams, jellies among others. These characteristics make them interesting for biotechnological, food, pharmaceutical and medical applications (Caramori et al., 2004; Cardoso et al., 2011).

The Combretaceae family is in the Myrtales class, which consists of 20 genus and approximately 600 species of trees or shrubs. The most studied genus of this family are: Combretum, Terminalia and Quisqualis. In Brazil, five native genus Buchenavia, Combretum, Conocarpus, Terminalia and Thiloa occur as well as two exotic ones, Bucida and Quisqualis (Souza \& Lorenzi, 2008). The species Buchenavia tomentosa Eichler is a native tree from the Cerradão (forest formation of the savannah biome) and semi-deciduous forest, with an average height of 5 to $12 \mathrm{~m}$ and trunk diameter of 30 to $50 \mathrm{~cm}$ (Lorenzi, 2008). This species is popularly known as mirindiba, embiridiba, tarumarana or tonimbuca (Costa et al., 2011). The husk of its stem is used in popular medicine in the form of tea in the treatment of cough, such as antihyperlipidemic and anorexigenic (Silva et al., 2010). In the North Araguaia microregion (Mato Grosso, Brazil) the bark, flowers and fruits are used by the riverine community in the treatment of the high cholesterol, diabetes, high blood pressure (Ribeiro et al., 2017).

Recent studies involving leaves extracts have demonstrated several antimicrobial activities against Escherichia coli, Pseudomonas aeroginosa, Staphylococcus aureus and Staphylococcus epidermidis (Girondi et al., 2017). It also has proven antifungal activity against Candida albicans, reducing its 
virulence factors, such as ability to form biofilms and adhesion in oral epithelial cells (Teodoro et al., 2015; Teodoro et al., 2018). The chemical characterization showed the presence of phenols compounds, such as the ellagic and gallic acids that demonstrated Candida albicans antibiofilm activity (Brighenti et al., 2017). The bark methanolic extracts also present phenolic compounds, resulting in high antioxidant activities (Teixeira et al., 2017).

Its fruiting occurs in the months of June, July, August and September. Its fruits have pulpy flesh which is sweet when ripe, containing a single seed (Lorenzi, 2008). They are consumed fresh as juice or sweet, and in popular medicine they are used in the treatment of cough (Ferreira et al., 2016). In some regions they are considered toxic, since their consumption could cause digestive alterations and abortions in goats, sheep and cattle (Mello et al., 2010).

However, such effects have not been observed in studies with rats. Nunes et al. (2010) observed mild toxicity, such as increased feed and weight gain in broodings of rats fed a $10 \%$ diet of $B$. tomentosa fruits. In another study, the fruits aqueous extract showed no androgenic or antiandrogenic activities, nor were observed degenerative, inflammatory alterations and did not trigger systemic toxicity on the animals (Ferreira et al., 2016).

Although several studies presented in the scientific literature for $B$. tomentosa, including pharmacological studies and ethnomedicinal reports, there are no studies that approach the physical, chemical and biochemical characterization of this plant species fruits. In this perspective, the present work aims to evaluate the physical and physicochemical characterization of $B$. tomentosa fruits collected in the central and southern regions of the Tocantins state.

\section{Materials and methods}

\subsection{Plant material}

The analyzed fruits were randomly collected from ten matrices in two regions of the Tocantins State, in the municipalities of Gurupi (southern region, samples 1, 2 and 3) and Palmas (central region, samples 4 and 5). The collects were carried out in 2013 between the months of July to October; when the plant reaches its peak of productivity. The fruits of $B$. tomentosa were harvested manually in the first hours of the morning, packed in plastic bags and thermal boxes and sent to the Laboratory of Post Harvest Physiology of Fruits and Vegetables, in the Food Science Department (UFLA). The fruits were washed in distilled water, selected by their state of conservation and absence of defects caused by pests and manually reduced, being separated into three replicates (each replicate formed by twenty fruits).

\subsection{Physical-chemical and biochemical analysis}

The MINOLTA CR-400 colorimeter was used to perform the color analysis, with determination in the CIE mode $\mathrm{L}^{*} \mathrm{a}^{*} \mathrm{~b}^{*}$. The variables $a^{\star}$ and $b^{\star}$ were used to calculate the $C^{\star}$ value (chromaticity) and ${ }^{\circ}$ (Hue angle) (MacGuire, 1992).

Following the methodologies proposed by the Association of Official Analytical Chemists (Association of Official Analytical Chemistry, 2005), the determination of centesimal composition, soluble solids, titratable acidity and $\mathrm{pH}$ were performed. The humidity was determined according to the gravimetric technique (in a ventilated oven), the ethereal extract fraction was evaluated in an intermittent Soxhlet extractor using hexane as extracting solvent. The Kjeldahl (semimicro) method was used for protein determination and the 6.25 factor was applied to convert to protein the total nitrogen content. The ash fraction was determined by gravimetry in a muffle oven at $550{ }^{\circ} \mathrm{C}$ until constant weight and the glycidic fraction (carbohydrate content) was obtained by difference (Association of Official Analytical Chemistry, 2005).

The total energetic value (TEV) was calculated by the sum of the calories (kcal) provided by carbohydrates, lipids and proteins, multiplying its values in grams by water factors $4 \mathrm{Kcal}$, $9 \mathrm{Kcal}$ and $4 \mathrm{Kcal}$, respectively (Instituto Adolfo Lutz, 2008).

The gross fiber determination was made by acid hydrolysis by the gravimetric method, according to the methodology described by Kamer \& Ginkel (1952). Soluble pectin content was determined according to the technique standardized by McCready \& McComb (1952) using a colorimetric method, based on hydrolyzed pectin reaction with galacturonic acid and carbazole, the results being expressed in $\mathrm{mg}$ of polygalacturonic acid $100 \mathrm{~g}^{-1}$ of fruit pulp. The total pectin content was obtained according to Bitter \& Muir (1962), with the results expressed

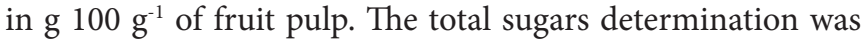
performed by the colorimetric method according to Dische (1962), with the results expressed in $\mathrm{g} 100 \mathrm{~g}^{-1}$ of fruit pulp.

In order to determine the Vitamin C levels two methods of extraction were used. In the first method, an oxalic acid (0.5\%) solution was used, and $50 \mathrm{~mL}$ of this solution were added to $5 \mathrm{~g}$ of the sample. The mixture was then triturated in polytron and homogenized on a stirrer for 30 minutes and filtered on filter paper. In the second extraction method, $50 \mathrm{~mL}$ of a metaphosphoric acid (1\%) solution were added to $5 \mathrm{~g}$ of the sample. The resulting mixture was triturated in polytron and homogenized on a stirrer for 3 minutes. After 5 minutes centrifugation at $3000 \mathrm{rpm}$ the supernatant was filtered on filter paper. The quantification of vitamin $\mathrm{C}$ in the extractions resulting solutions were performed by colorimetric method according to Strohercher \& Henning (1967), with the results expressed as mg of vitamin C per $100 \mathrm{~g}$ of fruit pulp.

The contents of phenolic compounds were determined from the extracts obtained by adding $40 \mathrm{~mL}$ of an aqueous methanol solution $(50 \% \mathrm{v} / \mathrm{v})$ to $5 \mathrm{~g}$ of the sample. The mixture was stirred for 60 minutes ( $50 \mathrm{rpm}$ ), and then centrifuged for 15 minutes at $14000 \mathrm{rpm}$ and the supernatant filtered. The total phenolics quantification was performed according to Waterhouse (2002), using the Folin Ciocalteau reagent. The results were expressed in grams of gallic acid equivalents per 100 grams of fresh pulp (g EAG $100 \mathrm{~g}^{-1}$ ).

\subsection{Statistical analysis}

The experimental design was completely randomized with three repetitions. The data were submitted to variance analysis and the means were compared by the Tukey test at $5 \%$ probability. All the analyses were made using the software SISVAR (Ferreira, 2011). 


\section{Results and discussion}

The obtained results for the color coordinates $\mathrm{L}^{\star}$ and the colorimetric indexes $\mathrm{C}^{\star}$ and ${ }^{\circ} \mathrm{h}$ are presented in Table 1. The obtained values for the brightness $\left(\mathrm{L}^{*}\right)$ and chromaticity $\left(C^{\star}\right)$ were below pure white $(100)$, what characterizes fruits with low light intensity and more opaque coloring.

According to the obtained values the B. tomentosa pulps and fruits presented a light color tone, with $\mathrm{L}^{*}$ varying from 42.81 to 47.62, close to fruits such as: Puteria caimito, Abiu or Guapeva (46.2), Eugenia stipitata, Arçá-boi (40.7); Spondias lutea, Cajá (47.9); Byrsonima crassifolia, Murici (45.8). It is superior to fruits such as Byrsonima verbascifolia, Murici-do-cerrado (41.69), whereas dark-colored fruits such as Euterpe oleracea (Açaí), Oenocarpus bacaba (Bacaba) and Campomanesia cambessedeana (Gabiroba) present $\mathrm{L}^{*}$ of 16.6; 26.8 and 26.09, respectively (Canuto et al., 2010; Morzelle et al., 2015).

A small variation was observed in relation to chromaticity for pulps and fruits with values between 14.36 to 17.27 and 15.56 to 18.89 , respectively. Characterizing their little intensity colorations. As for the tonality ( $\mathrm{o} h)$, for both pulp and fruits, it can be inferred that it tends to yellow with shades variation from 98 to $110^{\circ} \mathrm{h}$. The matrices data of $\left(\mathrm{L}^{\star}\right),\left(\mathrm{C}^{\star}\right)$ and $\left({ }^{\circ} \mathrm{h}\right)$ analyzed demonstrate that the $B$. tomentosa fruits present a yellow-orange coloration.

The B. tomentosa fruits presented ${ }^{\circ}$ Brix variable from 22.33 to 25.33, as can be observed in Table 2 .

These values are higher than those found for some fruits such as araçá (Psidum cattleianum) with $10.7^{\circ}$ Brix (Damiani et al., 2011), carambola (Averrhoa carambola) with ${ }^{\circ}$ Brix from 6.4 to 9.0 (Oliveira et al., 2012), Araticunzeiro (Annona crassiflora Mart.) from 16.89 to $20.91{ }^{\circ}$ Brix (Braga et al., 2014). The $\mathrm{pH}$ values were found for B. tomentosa fruits ranging from 3.44 to 3.73 (Table 2), showing a high acidity for this fruit when compared to other fruits considered acid such as gabiroba (4.25) and murici (4.75) (Morzelle et al., 2015). Regarding to titratable acidity (TA), there was no significant difference $(\mathrm{p} \leq 0.05)$ and the matrices overall average was 1.95 . The ratio relation (SS/AT), which demonstrates the equilibrium between SS and AT and which is directly related to the fruit flavor (Chitarra \& Chitarra, 2005), shows that sample 1 has the sweetest fruits and the sample 3 the most acid fruits. Regarding to the values of total soluble sugars (TSSU) expressed as a percentage, only sample 2 differed statistically from the others, presenting the

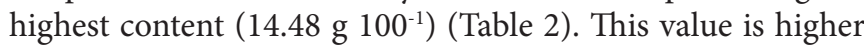
than mangaba (12.98\%) and bacuri (11.27\%), however, lower than sapoti (22.46\%), pinha (19.23\%) and seriguela (18.68\%) (Alves et al., 2000).

Still observing the data presented in Table 2, it is possible to verify that the total pectin contents for the samples of $B$. tomentosa

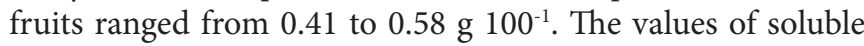
pectin were higher than those presented by cajá $(0.07 \%)$, close to fruits such as pinha $(0.31 \%)$, bacuri $(0.19 \%)$, mangaba $(0.24 \%)$, araçá $(0.24 \%)$ and lower than sapoti fruits $(0.60 \%)$ (Alves et al., 2000; Damiani et al., 2011).

The centesimal composition and caloric value of the analyzed B. tomentosa fruits pulps are presented in Table 3.

The humidity content varied from 75.27 to $78.51 \%$, with the highest levels presented by samples 1 (78.51\%) and 2 (78.43\%). The studied fruits presented lower contents of those presented by fruits such as araçá (82.36\%), cagaita (93.34\%), cajú-do-cerrado

Table 1. Average values of brightness (L), chromaticity (C) and Hue angle ( $\left.{ }^{\circ} \mathrm{h}\right)$ for Buchenavia tomentosa fruits.

\begin{tabular}{ccccccccc}
\hline Matrices & Fruit part & L & C & oh & Fruit part & L & C \\
\hline Sample 1 & Pulp $^{*}$ & $44.30 \mathrm{a}$ & $14.56 \mathrm{a}$ & $101 \mathrm{ab}$ & Fruit $^{* *}$ & $45.07 \mathrm{a}$ & $15.56 \mathrm{a}$ & $108 \mathrm{bc}$ \\
Sample 2 & Pulp $^{*}$ & $47.62 \mathrm{~b}$ & $17.27 \mathrm{~b}$ & $103 \mathrm{~b}$ & Fruit $^{* *}$ & $42.81 \mathrm{a}$ & $17.95 \mathrm{bc}$ & $107 \mathrm{~b}$ \\
Sample 3 & Pulp $^{*}$ & $45.14 \mathrm{a}$ & $14.36 \mathrm{a}$ & $100 \mathrm{ab}$ & Fruit $^{* *}$ & $45.35 \mathrm{a}$ & $17.63 \mathrm{bc}$ & $110 \mathrm{a}$ \\
Sample 4 & Pulp $^{*}$ & $47.46 \mathrm{~b}$ & $17.21 \mathrm{~b}$ & $98 \mathrm{a}$ & Fruit $^{*}$ & $45.43 \mathrm{a}$ & $18.89 \mathrm{c}$ & $110 \mathrm{~b}$ \\
Sample 5 & Pulp & $43.37 \mathrm{a}$ & $16.63 \mathrm{~b}$ & $100 \mathrm{ab}$ & Fruit $^{*}$ & $44.91 \mathrm{a}$ & $17.11 \mathrm{~b}$ & $104 \mathrm{c}$ \\
Average & & 45.58 & 16.01 & 100.67 & & 44.71 & 17.43 & 108.20 \\
CV (\%) & & 1.83 & 3.15 & 1.66 & & 2.20 & 3.18 & 0.72 \\
\hline
\end{tabular}

${ }^{*}$ mesocarp and endocarp; ${ }^{* *}$ only the pericarp; ${ }^{* * *} \mathrm{CV}=$ Coefficient of variation; Averages followed by the same letter, in the columns, do not differ by the Tukey test ( $\left.\mathrm{p}<0.05\right)$.

Table 2. Average values of hydrogen potential ( $\mathrm{pH}$ ), total soluble solids (TSS), titratable acidity (TA), ratio (SST/AT), total soluble sugars (TSSU), total pectin (TP) and soluble pectin (SP) of Buchenavia tomentosa fruits.

\begin{tabular}{cccccccc}
\hline $\begin{array}{c}\text { Analyzed } \\
\text { matrices }\end{array}$ & $\mathrm{pH}$ & TSS & TA* & SST/AT & TSSU & TP \\
\hline Sample 1 & $3.73 \mathrm{c}$ & $23.42 \mathrm{a}$ & $1.66 \mathrm{a}$ & $14.11 \mathrm{a}$ & $11.08 \mathrm{a}$ & $0.41 \mathrm{a}$ & $0.19 \mathrm{a}$ \\
Sample 2 & $3.61 \mathrm{~b}$ & $22.33 \mathrm{a}$ & $1.75 \mathrm{a}$ & $12.76 \mathrm{a}$ & $14.48 \mathrm{~b}$ & $0.58 \mathrm{~b}$ & $0.27 \mathrm{~b}$ \\
Sample 3 & $3.48 \mathrm{a}$ & $23.67 \mathrm{a}$ & $2.18 \mathrm{a}$ & $10.85 \mathrm{a}$ & $11.52 \mathrm{a}$ & $0.51 \mathrm{ab}$ & $0.23 \mathrm{ab}$ \\
Sample 4 & $3.44 \mathrm{a}$ & $25.33 \mathrm{~b}$ & $2.17 \mathrm{a}$ & $11.67 \mathrm{a}$ & $11.88 \mathrm{a}$ & $0.51 \mathrm{ab}$ & $0.29 \mathrm{~b}$ \\
Sample 5 & $3.44 \mathrm{a}$ & $23.00 \mathrm{a}$ & $2.01 \mathrm{a}$ & $11.44 \mathrm{a}$ & $10.34 \mathrm{a}$ & $0.48 \mathrm{ab}$ & $0.47 \mathrm{c}$ \\
Average & 3.54 & 23.55 & 1.95 & & 11.86 & 0.50 & 0.29 \\
CV (\%) & 0.42 & 2.34 & 13.88 & & 4.84 & 12.43 & 7.88 \\
\hline
\end{tabular}

Averages followed by the same letter in the columns do not differ by the Tukey test $(\mathrm{p}<0.05)$; ${ }^{\star}$ Equivalent in citric acid; ${ }^{* *} \mathrm{CV}=\mathrm{Coefficient}$ of variation. 
Table 3. Humidity content, ethereal extract, gross protein, gross fiber, ash, glycidic fraction and total energetic value (TEV) of the Buchenavia tomentosa fruits pulp.

\begin{tabular}{ccccccc}
\hline $\begin{array}{c}\text { Analyzed } \\
\text { matrices }\end{array}$ & Humidity & Ethereal extract & Gross protein & Gross fiber & Ash & Glycidic fraction \\
\hline Sample 1 & $78.51 \mathrm{a}$ & $0.06 \mathrm{~d}$ & $0.10 \mathrm{~b}$ & $0.04 \mathrm{c}$ & $0.02 \mathrm{~b}$ & $20.21 \mathrm{~b}$ \\
Sample 2 & $78.43 \mathrm{a}$ & $0.38 \mathrm{c}$ & $0.11 \mathrm{~b}$ & $0.04 \mathrm{cb}$ & $0.71 \mathrm{a}$ & $20.26 \mathrm{~b}$ \\
Sample 3 & $77.26 \mathrm{~b}$ & $0.98 \mathrm{~b}$ & $0.11 \mathrm{~b}$ & $0.05 \mathrm{cb}$ & $0.78 \mathrm{a}$ & $20.72 \mathrm{~b}$ \\
Sample 4 & $75.27 \mathrm{c}$ & $1.38 \mathrm{a}$ & $0.12 \mathrm{~b}$ & $0.07 \mathrm{~b}$ & $0.80 \mathrm{a}$ & $20.87 \mathrm{~b}$ \\
Sample 5 & $77.29 \mathrm{~b}$ & $1.01 \mathrm{~b}$ & $1.15 \mathrm{a}$ & $0.18 \mathrm{a}$ & $0.80 \mathrm{a}$ & $22.25 \mathrm{a}$ \\
Average & 73.35 & 0.76 & 0.32 & 0.08 & 0.62 & 20.86 \\
CV $(\%)^{*}$ & 0.29 & 5.02 & 4.50 & 17.32 & 14.20 & $91.69 \mathrm{~b}$ \\
\hline
\end{tabular}

Averages followed by the same vertical letter do not have significant difference by the Tukey test $(\mathrm{p}<0.05)$; ${ }^{*} \mathrm{CV}=\mathrm{Coefficient}$ of variation.

(86.57\%), mangaba (82.40\%), murici (80.64\%), pitomba (83.16\%), puçá $(85.13 \%)$; and were lower than those found for chichá (6.95\%) and macaúba (34.32\%) (Roesler et al., 2007; Silva et al., 2008). However, the ethereal extract contents varied from 1.38 to $0.06 \%$, being close to those presented by other fruits such as: cagaita $(0.82 \%)$, cajú-do-cerrado $(0.63 \%)$ and curriola (0.84\%) (Silva et al., 2008; Gordon et al., 2012; Morzelle et al., 2015). However, they were lower in comparison to the results found in other savannah fruits, such as gabiroba (1.32\%) and murici (2.31\%) (Morzelle et al., 2015).

Protein contents were very similar among the samples, close to $0.10 \%$, except for sample 5 , which had a content (1.15) higher than those determined for the other samples. These values show a low protein potential for $B$. tomentosa fruits when compared to other fruits such as araticum (1.22\%), cajú-do-cerrado (1.18\%), mangaba (1.20\%), açaí (21\%), guapeva (1.88\%), murici (1.94\%), gabiroba (1.43\%) and Curriola (2.08\%), which present higher protein values than the general average of $B$. tomentosa fruits (Roesler et al., 2007; Silva et al., 2008; Gordon et al., 2012; Morzelle et al., 2015; Siqueira et al., 2017). In relation to the gross fiber contents, these were also low, being inferior to those of curriola (1.06\%), gabiroba ( $0.41 \%)$ and murici $(1.02 \%)$. Low values were also found for ash contents ranging from 0.80 to 0.02 , much lower than those present in the curriola $(8.18 \%)$, gabiroba (4.14\%) and murici (4.98\%) fruits (Morzelle et al., 2015).

However, the glycidic content of $B$. tomentosa fruits, with an average value of 20.86, showed relatively high carbohydrate contents, compared to those reported for puça fruits $(6.64 \%)$, araticum $(3.83 \%)$, mangaba $(1.20 \%)$, gabiroba $(11.6 \%)$, guapeva $(12.23 \%)$, curriola $(17.16 \%)$, gabiroba $(15.68 \%)$ and murici (18.85\%) (Silva et al., 2008; Morzelle et al., 2015; Siqueira et al., 2017). As for the caloric value, which varied from $81.78 \mathrm{Kcal}$ to $102.69 \mathrm{kcal}$, these fruits can be considered relatively caloric, when compared to fruits of araçá (37 kcal), cagaita (20 kcal) (Souza et al., 2012).

B. tomentosa fruit pulps presented high vitamin $\mathrm{C}$ content, ranging from 1265.59 to $3573.50 \mathrm{mg}$ ascorbic acid per $100 \mathrm{~g}$ of pulp, as can be observed in Table 4.

The vitamin $C$ levels presented by the $B$. tomentosa fruits are higher than those presented by fruits known to have high contents of this compound, such as the fruits of acerola (Malpighia emarginata) that presented levels ranging from
Table 4. Vitamin C and total phenolic content of Buchenavia tomentosa fruits samples.

\begin{tabular}{ccc}
\hline $\begin{array}{c}\text { Analytical } \\
\text { matrices }\end{array}$ & $\begin{array}{c}\text { Vitamin C } \\
\left(\mathrm{g} \text { ascorbic acid } 100 \mathrm{~g}^{-1}\right)\end{array}$ & $\begin{array}{c}\text { Phenolic compounds } \\
\left(\mathrm{g} \mathrm{GAE} 100 \mathrm{~g}^{-1}\right)\end{array}$ \\
\hline Sample 1 & $1.70 \mathrm{c}$ & $3.12 \mathrm{~b}$ \\
Sample 2 & $2.74 \mathrm{~b}$ & $2.96 \mathrm{~b}$ \\
Sample 3 & $3.57 \mathrm{a}$ & $3.27 \mathrm{~b}$ \\
Sample 4 & $1.26 \mathrm{~d}$ & $4.20 \mathrm{a}$ \\
Sample 5 & $2.63 \mathrm{~b}$ & $2.93 \mathrm{~b}$ \\
Average & 2.37 & 3.30 \\
CV $(\%)^{*}$ & 6.70 & 7.14 \\
\hline
\end{tabular}

Averages followed by the same letter in the columns do not differ by the Tukey test $(\mathrm{p}<0.05) ;{ }^{*} \mathrm{CV}=$ Coefficient of variation.

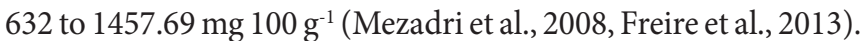
The vitamin $C$ concentration present in the $B$. tomentosa fruits is also higher than the levels in camu-camu fruits (Myrciaria dubia), 2061.04 and $1882 \mathrm{mg} 100 \mathrm{~g}^{-1}$ (Alves et al., 2000; Rufino et al., 2011). These results demonstrate that the $B$. tomentosa fruits are among the fruits with higher amounts of vitamin C.

In relation to the contents of phenolic compounds presented by $B$. tomentosa fruit pulp, a variation of 2933.51 to $4200.33 \mathrm{mg}$ GAE $100 \mathrm{~g}^{-1}$ was observed, as can be observed in Table 4. These levels cause this fruit, besides being a great source of vitamin $\mathrm{C}$ be also rich in phenolic compounds, considering the concentrations of phenolic compounds presented by known fruits. The amount of phenolic compounds from $B$. tomentosa fruit pulps were higher than those determined by Denardin et al. (2015) for fruits such as araçá, butiá, pitanga with orange, red and purple pulp, mulberry from cultivars Xavante and Cherokee cultive, with respective contents equal to $457.43,359.50,660.19,457.43,433.84,799.80$,

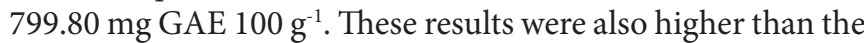
values (expressed as mg GAE $100 \mathrm{~g}^{-1}$ ) found for several fruits of Amazonian and Brazilian savannah species, such as camu-camu (1400) Araticum (580), Cagaita (200), Jenipapo (651), Lobeira (1.166), Jabuticaba (1.15, methanolic extract 1.04 ethanolic), Guapeva (79.00, pulp and 474.10, husk), Cagaita (141.95), Cajú-do-cerrado (160.74), Gabiroba (1222.59) (Neves et al., 2012; Siqueira et al., 2013; Naspolini et al., 2016; Siqueira et al., 2017). However, the found values are similar to those reported for açaí fruit, with $3437 \mathrm{mg} \mathrm{GAE} 100 \mathrm{~g}^{-1}$ (Gordon et al., 2012), which is a known fruit rich in phenolic compounds. 
The high levels of vitamin $\mathrm{C}$ and phenolic compounds presented by the $B$. tomentosa fruits confer significant nutritional properties in view of the effects of these compounds on the human body. It is now known that vitamin $\mathrm{C}$ is involved in several biological processes, such as in the collagen and adrenaline synthesis, bile acids formation and some neurotransmitters (Baynes \& Dominiczak, 2015). Phenolic compounds, due to their antioxidant properties, contribute to the reduction of the incidence of chronic and degenerative diseases (Mena \& Llorach, 2017). They may also present anti-inflammatory, antimicrobial and anticarcinogenic activities (Mojzer et al., 2016).

\section{Conclusion}

Based on this study obtained data, the B. tomentosa fruits were potentially nutritious, with a significant number of sugars (carbohydrates), phenolic compounds and vitamin C. These fruits also had significant soluble solids contents, which may favor the degree of sweetness in relation to the acid. Thus, the fruits under study can be characterized as acid, slightly sweet, and of little yellow coloration.

\section{Acknowledgements}

We thank "Conselho Nacional de Desenvolvimento Científica e Tecnológico" (CNPq), "Fundação de Amparo à Pesquisa de Minas Gerais" (FAPEMIG) and "Rede Mineira de Química" (RQ-MG) (Project: CEX-RED-0010-14).

\section{References}

Alves, R. E., Filgueiras, H. A. C., \& Moura, C. F. H. (2000). Characterization of native fruits of Latin America. Jaboticabal: FUNEP.

Association of Official Analytical Chemistry - AOAC. (2005). Official methods of analysis of the Association of Official Analytical Chemists (18th ed.). Gaithersburg: AOAC.

Baynes, J. W., \& Dominiczak, M. H. (2015). Medical biochemistry (4th ed.). Rio de Janeiro: Elsevier.

Bitter, T., \& Muir, H. M. (1962). A modified uronic acid carbazole reaction. Analytical Biochemistry, 4(4), 330-334. http://dx.doi. org/10.1016/0003-2697(62)90095-7. PMid:13971270.

Braga, J. R., Naves, R. V., Chaves, L. J., Pires, L. L., \& Mazon, L. T. (2014). Physical and physical and chemical characterization of Araticum fruits (Annona crassiflora MART.). Bioscience Journal, 30(1), 16-24.

Brighenti, F. L., Salvador, M. J., Gontijo, A. V. L., Delbem, A. C. B., Delbem, Á. C. B., Soares, C. P., Oliveira, M. A. C., Girondi, C. M., \& Koga-Ito, C. Y. (2017). Plant extracts: initial screening, identification of bioactive compounds and effects against Candida albicans biofilms. Future Microbiology, 12(1), 15-27. http://dx.doi.org/10.2217/fmb2016-0094. PMid:27922746.

Canuto, G. A. B., Xavier, A. A. O., Neves, L. C., \& Benassi, M. T. (2010). Physical-chemical characterization of fruit pulps from Amazonia and their correlation with free radical anti-free activity. Revista Brasileira de Fruticultura, 32(4), 1196-1205. http://dx.doi.org/10.1590/S010029452010005000122.

Caramori, S. S., Lima, C. S., \& Fernandes, K. F. (2004). Biochemical characterization of selected plant Species from Brazilian Savannas. Brazilian Archives of Biology and Technology, 47(2), 253-259. http:// dx.doi.org/10.1590/S1516-89132004000200013.
Cardoso, L. M., Martino, H. S. D., Moreira, A. V. B., Ribeiro, S. M. R., \& Pinheiro-Sant'Ana, H. M. (2011). Cagaita (Eugenia dysenterica DC.) of the Cerrado of Minas Gerais, Brazil: Physical and chemical characterization, carotenoids and vitamins. Food Research International, 44(7), 2151-2154. http://dx.doi.org/10.1016/j.foodres.2011.03.005.

Chitarra, M. I. F., \& Chitarra, A. B. (2005). Post-harvesting of fruits and vegetables: physiology and handling (2nd ed.) Lavras: UFLA.

Costa, A. M. D., Souza, D. P. M., Cavalcante, T. V., Araújo, V. L., Ramos, A. T., \& Maruo, V. M. (2011). Toxic plants of animal interest in an Amazonian and cerrado ecotone region Part II. Acta Veterinaria Brasilica, 5(3), 317-324.

Damiani, C., Boas, E. V. B. V., Asquieri, E. R., Lage, M. E., Oliveira, R. A., Silva, F. A., Pinto, D. M., Rodrigues, L. J., Silva, E. P., \& Paula, N. R. F. (2011). Characterization of the fruits of the Cerrado: Araçá (Psidium guineense Sw.) and Marolo (Annona crassiflora Mart.). Food Science and Technology, 31(3), 723-729. http://dx.doi.org/10.1590/ S0101-20612011000300026.

Denardin, C. C., Hirsch, G. E., Rocha, R. F., Vizzotto, M., Henriques, A. T., Moreira, J. C. F., Guma, F. T. C. R., \& Emanuelli, T. (2015). Antioxidant capacity and bioactive compounds of four Brazilian native fruits. Journal of Food and Drug Analysis, 23(3), 387-398. http://dx.doi.org/10.1016/j.jfda.2015.01.006. PMid:28911695.

Dische, Z. (1962). General color reactions. In R. L. Whistler, \& M. L. Wolfran (Eds.), Carboydrates chemistry (chap. 1, pp. 477-512). New York: Academic Press.

Ferreira, D. F. (2011). Sisvar: a computer statistical analysis system. Ciência e Agrotecnologia, 35(6), 1039-1042. http://dx.doi.org/10.1590/ S1413-70542011000600001.

Ferreira, M. D. S., Moura, E. R., Batista, E. K. F., Silva, S. M. M. S., Cardoso, F. C. Fo., \& Batista, M. C. S. (2016). Evaluation of the reproductive toxic potential of buchenavia sp fruit extract in male impersonal wistar rats. Archives of Veterinary Science, 21(2), 79-86. http://dx.doi.org/10.5380/avs.v21i2.47849.

Freire, J. M., Abreu, C. M. P., Rocha, D. A., Corrêa, A. D., \& Marques, N. R. (2013). Quantification of phenolic compounds and ascorbic acids in fruits and frozen pulp of acerola, cashew, guava and strawberry. Ciência Rural, 43(12), 2291-2295. http://dx.doi.org/10.1590/S010384782013005000132 .

Girondi, C. M., Oliveira, A. B., Prado, J. A., Koga-Ito, C. Y., Borges, A. C., Delbem, A. C. B., Pereira, D. F. A., Salvador, M. J., \& Brighenti, F. L. (2017). Screening of plants with antimicrobial activity against enterobacteria, Pseudomonas spp. and Staphylococcus spp. Future Microbiology, 12(8), 671-681. http://dx.doi.org/10.2217/fmb-20160129. PMid:28541127.

Gordon, A., Cruz, A. P., Cabral, L. M., Freitas, S. C., Taxi, C. M., Donangelo, C. M., Mattietto, R. A., Friedrich, M., Matta, V. M., \& Marx, F. (2012). Chemical characterization and evaluation of antioxidant proprieties of açaí fruits (Euterpe oleraceae Mart.) during ripening. Food Chemistry, 133(2), 256-263. http://dx.doi. org/10.1016/j.foodchem.2011.11.150. PMid:25683393.

Instituto Adolfo Lutz - IAL. (2008). Métodos físico-químicos para análise de alimentos (4. ed.). São Paulo: IAL.

Kamer, S. B., \& Ginkel, L. (1952). Rapid determination of crude fiber in cereals. Cereal Chemistry, 9(4), 239-251.

Lorenzi, H. (2008). Brazilian Trees: manual of identification and cultivation of tree plants of Brazil (3rd ed.). Nova Odessa: Instituto Plantarum.

MacGuire, R. G. (1992). Reporting of objective color measurements. HortScicence, 27, 1254-1255. 
McCready, P. M., \& McComb, E. A. (1952). Extraction and determination of total pectin materials. Analytical Chemistry, 24(12), 1586-1588. http://dx.doi.org/10.1021/ac60072a033.

Mello, G. W. S., Oliveira, D. M., Carvalho, C. J. S., Pires, L. V., Costa, F. A. L., Riet-Correa, F., \& Silva, S. M. M. (2010). Toxic plants for ruminants and equidae in northern Piauí. Pesquisa Veterinária Brasileira, 30(1), 1-9. http://dx.doi.org/10.1590/S0100-736X2010000100001.

Mena, P., \& Llorach, R. (2017). New frontiers on the metabolism, bioavailability and health effects of phenolic compounds. Molecules, 22(1), 151. http://dx.doi.org/10.3390/molecules22010151. PMid:28106749.

Mezadri, T., Villaño, D., Fernández-Pachón, M. S., García-Parrilla, M. C., \& Troncoso, A. M. (2008). Antioxidant compounds and antioxidant activity in acerola (Malpighia emarginata DC.) fruits and derivatives. Journal of Food Composition and Analysis, 21(4), 282-290. http://dx.doi.org/10.1016/j.jfca.2008.02.002.

Mojzer, E. B., Hrnčič, M. K., Škerget, M., Knez, Ž., \& Bren, U. (2016). Polyphenols: extraction methods, antioxidative action, bioavailability and anticarcinogenic effects. Molecules, 21(7), 901. http://dx.doi. org/10.3390/molecules21070901. PMid:27409600.

Morzelle, M. C., Bachiega, P., Souza, E. C. D., Boas, E. V. D. V., \& Lamounier, M. L. (2015). Chemical and physical characterization of Curriola, Gabiroba and Murici fruits from the Cerrado Brasileiro. Revista Brasileira de Fruticultura, 37(1), 96-103. http://dx.doi. org/10.1590/0100-2945-036/14.

Naspolini, N. F., Seljan, M. P., Santos, M. C. P., \& Gonçalves, É. C. B. A. (2016). Phytochemical characterization of bioactive compounds on methanolic and ethanolic leaf extracts of Myrciaria sp. Scientia Agropecuaria, 7(2), 103-109. http://dx.doi.org/10.17268/sci. agropecu.2016.02.03.

Neves, L. C., Campos, A. J., Benedette, R. M., Tosin, J. M., \& Chagas, E. A. (2012). Characterization of the antioxidant capacity of natives fruits from the Brazilian amazon region. Revista Brasileira de Fruticultura, 34(4), 1165-1173. http://dx.doi.org/10.1590/S010029452012000400025.

Nunes, H. M. M., Paiva, J. A., Ramos, A. T., Maiorka, P. C., \& Maruo, V. M. (2010). Effects of Buchenavia tomentosa consumption on female rats and their offspring. Acta Scientiarum. Biological Sciences, 32(4), 423-429.

Oliveira, V. B., Yamada, L. T., Fagg, C. W., \& Brandão, M. G. L. (2012). Native foods from Brazilian biodiversity as a Source of bioactive compounds. Food Research International, 48(1), 170-179. http:// dx.doi.org/10.1016/j.foodres.2012.03.011.

Ribeiro, R. V., Bieski, I. G. C., Balogun, S. O., \& Martins, D. T. O. (2017). Ethnobotanical study of medicinal plants used by ribeirinhos in the North Araguaia microregion, Mato Grosso, Brazil. Journal of Ethnopharmacology, 205, 69-102. http://dx.doi.org/10.1016/j. jep.2017.04.023. PMid:28476677.

Roesler, R., Catharino, R. R., Malta, L. G., Eberlin, M. N., \& Pastore, G. (2007). Antioxidant activity of Annona crassiflora: Characterization of major components by electrospray ionization mass spectrometry. Food Chemistry, 104(3), 1048-1054. http://dx.doi.org/10.1016/j. foodchem.2007.01.017.

Rufino, M. S. M., Alves, R. E., Fernandes, F. A. N., \& Brito, E. S. (2011). Free radical scavening behavior of tem exotic tropical fruits extracts.
Food Research International, 44(7), 2072-2075. http://dx.doi. org/10.1016/j.foodres.2010.07.002.

Silva, M. A. B., Melo, L. V. L., Ribeiro, R. V., Souza, J. P. M., Lima, J. C. S., Martins, D. T. O., \& Silva, R. M. (2010). Ethnobotanical survey of plants used as antihyperlipidemic and anorexigenic by the population of Nova Xavantina-MT, Brazil. Revista Brasileira de Farmacognosia, 20(4), 549-562. http://dx.doi.org/10.1590/S0102-695X2010000400014.

Silva, M. R., Lacerda, D. B. C. L., Santos, G. G., \& Martins, D. M. O. (2008). Chemical characterization of native fruits of cerrado. Ciência Rural, 38(6), 1790-1793. http://dx.doi.org/10.1590/S010384782008000600051.

Siqueira, A. P. S., Oliveira, J. D. M., Machado, D. R. Jr., \& Lourenço, M. F. D. C. (2017). Chemical characterization and antioxidant capacity of Guapeva. Revista Brasileira de Fruticultura, 39(spe), e584. http:// dx.doi.org/10.1590/0100-29452017584.

Siqueira, E. M., Rosa, F. R., Fustinoni, A. M., Sant'Ana, L. P., \& Arruda, S. F. (2013). Brazilian savanna fruits contain higher bioactive compounds content and higher antiocidant activity relative to the conventional red delicious apple. PLoS One, 8(8), e72826. http:// dx.doi.org/10.1371/journal.pone.0072826. PMid:23991156.

Souza, V. C., \& Lorenzi, H. (2008). Systematic botany: illustrated guide for identification of families of native and exotic Phanerogams in Brazil, based on APG II. Nova Odessa: Instituto Plantarum.

Souza, V. R., Pereira, P. A. P., Queiroz, F., Borges, S. V., \& Carneiro, J. D. S. (2012). Determination of bioactive compounds, antioxidante activity and chemical composition of Cerrado Brazilian fruits. Food Chemistry, 134(1), 381-386. http://dx.doi.org/10.1016/j. foodchem.2012.02.191.

Strohercher, R. L., \& Henning, H. M. (1967). Vitamin analysis: proven methods. Madrid: Paz Montalvo.

Teixeira, T. S., Vale, R. C., Almeida, R. R., Ferreira, T. P. S., \& Guimarães, L. G. L. (2017). Antioxidant pontential and its correlation with the contents of phenolic compounds and flavonoids of methanolic extracts from different medicinal plants. Revista Virtual de Química., 9(4), 1546-1559. http://dx.doi.org/10.21577/1984-6835.20170090.

Teodoro, G. R., Brighenti, F. L., Delbem, A. C., Delbem, Á. C., Khouri, S., Gontijo, A. V., Pascoal, A. C., Salvador, M. J., \& Koga-Ito, C. Y. (2015). Antifungal activity of extracts and isolated compounds from Buchenavia tomentosa on Candida albicans and non-albicans. Future Microbiology, 10(6), 917-927. http://dx.doi.org/10.2217/fmb.15.20. PMid:26059616.

Teodoro, G. R., Gontijo, A. V. L., Salvador, M. J., Tanaka, M. H., Brighenti, F. L., Delbem, A. C. B., Delbem, A. C. B., \& Koga-Ito, C. (2018). Effects of acetone fraction from Buchenavia tomentosa aqueous extract and gallic acid on Candida albicans biofilms and virulence factors. Frontiers in Microbiology, 9, 647. http://dx.doi. org/10.3389/fmicb.2018.00647. PMid:29675005.

Waterhouse, A. L. (2002). Polyphenolics: determination of total phenolics In: R. E. Wrolstad (Ed.), Current protocols in food analytical chemistry (chap. II, pp. 257-326). New York: John Wiley. 